Kelola

Jurnal Manajemen Pendidikan

Magister Manajemen Pendidikan

ISSN 2443-0544

FKIP Universitas Kristen Satya Wacana

Volume: 3, No. 1, Januari-Juni 2016

jurnalkelola@gmail.com

Halaman: 98-114

\title{
STRATEGI PENGELOLAAN SEKOLAH TINGGI BERASRAMA DI KABUPATEN \\ SEMARANG
}

Noveliza Rudyolindy Theodora Tepy;

Alumni Program Pascasarjana Magister Manajemen Pendidikan

FKIP-Universitas Kristen Satya Wacana

novelizatepy@yahoo.com

\begin{abstract}
The purpose of this study was to: (1) Determine and analyze the boarding management strategies that have been used by STT Sangkakala; (2) to analyze the root problems in the management of a boarding high school in STT Sangkakala; (3) Design and produce strategies that can be implemented by STT Sangkakala in the management of a boarding high school. Design of this research is the development, but in this study is limited to the fifth stage, namely the revision of product design, where the product that produced a strategic plan for the management of the boarding college at STT Sangkakala Kopeng. Data analysis technique used fishbone anlysis. Data collection techniques used observation, interview, document studies, and FGD. Meanwhile, data validation was done by using tianggulasi source. The results of this analysis, a strategy that is based on the analysis fishbone, includes four factors: (1) curriculum management strategies and coaching; (2) management strategies of learners; (3) management strategies educators; and (4) strategies in the policy leader. Furthermore, the foundations, the chairman (rector), lecturers and other staff are expected to optimize the implementation of the strategic plan that has been prepared.
\end{abstract}

Keywords: Strategic Plan, Boarding School Management

\section{PENDAHULUAN}

Dalam Undang-Undang Sistem Pendidikan Nasional Nomor 20 tahun 2003 Pasal 1 disebutkan bahwa pendidikan merupakan usaha sadar dan terencana untuk mewujudkan suasana belajar dan proses pembelajaran agar peserta didik secara aktif mengembangkan potensi dirinya. Potensi diri tersebut antara lain mencakup kekuatan spiritual keagamaan, pengendalian diri, kepribadian, kecerdasan, akhlak mulia, serta keterampilan yang diperlukan dirinya, masyarakat, bangsa dan negara. Usaha sadar yang dimaksud yaitu bahwa proses pendidikan haruslah senantiasa dalam suasana yang mendukung tujuan dari pendidikan.

Salah satu sistem yang dapat mendukung pemaparan di atas yaitu melalui penyelenggaraan pendidikan dengan sistem asrama. Penyelenggaraan pendidikan dengan sistem asrama akan dapat mengarahkan dan mengontrol peserta didik dalam 
kesehariannya untuk dapat menerapkan hal-hal yang mereka pelajari. Pembelajaran dalam sistem asrama lebih mengacu kepada pendidikan secara holistik. Menurut Williams, 2011 dalam Papworth (2014) sekolah berasrama dirancang dan diperuntukkan bagi para peserta didik untuk membentuk sikap, perilaku, serta karakter yang sesuai dengan visi/misi sekolah dimana para peserta didik (berasrama) didampingi oleh guru/senior yang dapat memantau perkembangannya secara berkelanjutan. Para peserta didik yang tinggal di asrama dilengkapi dengan berbagai fasilitas untuk menunjang pembelajaran serta pembentukan karakter. Melalui sistem sekolah berasrama berbagai aktifitas yang dirancang merupakan aktifitas-aktifitas yang dapat memotivasi para peserta didik (berasrama) untuk mencapai visi/misi yang telah ditetapkan. Papworth (2014) memaparkan bahwa asrama sebagai lingkungan pendidikan memiliki ciri-ciri antara lain: sewaktu-waktu atau dalam waktu tertentu hubungan anak dengan keluarganya menjadi terputus atau dengan sengaja terputus dimana dalam waktu yang bersamaan anak-anak tersebut akan hidup bersama temanteman sebayanya dalam lingkungan asrama. Jenis dan bentuk asrama itu bermacammacam sesuai dengan kepentingan dan tujuan dari pengadaannya sebagai bentuk lingkungan pendidikan.

Melalui beberapa pemaparan mengenai konsep asrama di atas, maka dapat disimpulkan bahwa asrama merupakan suatu wadah dalam lingkungan pendidikan dimana peserta didik hidup secara mandiri (tidak bersama-sama dengan keluarga) yang dipersiapkan melalui berbagai aktifitas pembelajaran dan pembentukan karakter yang ditunjang dengan fasilitas lengkap dengan tujuan utama yaitu untuk mencapai visi/misi dari institusi lembaga pendidikan tertentu. Penjabaran mengenai faktor-faktor yang berpengaruh terhadap pengelolaan pendidikan berasrama menurut Tan (2014):

a. Pengelolaan Kurikulum dan Pembinaan

Pengelolaan kurikulum dan pembinaan merupakan faktor pengelolaan sekolah berasrama yang menjadi salah satu penentu keberhasilan tercapainya visi dan misi sekolah. Melalui pengelolaan kurikulum dan pembinaan yang tepat sasaran terhadap peserta didik maka visi dan misi sekolah dapat tercapai secara efektif dan efisien.

b. Pengelolaan Peserta Didik

Pengelolaan peserta didik ini terkait mengenai proses pembentukan karakter serta kesuksesan secara holistik yang seharusnya dicapai oleh setiap peserta didik yang menempuh pendidikan berasrama. 
c. Pengelolaan Tenaga Pendidik dan Kependidikan

Pengelolaan tenaga pendidik dan kependidikan merupakan faktor pengelolaan terkait kualifikasi tenaga pengajar dan pembina asrama (orangtua asrama/kepala asrama). Kualifikasi tenaga pengajar dan pembina asrama merupakan salah satu faktor yang penting peranannya dalam menjalankan pendidikan berasrama oleh karena pihak-pihak tersebut berperan secara langsung di lapangan dalam pembentukan kesuksesan peserta didik secara holistik.

d. Pengelolaan Sarana dan Prasarana

Pengelolaan sarana prasarana terkait segala fasilitas yang dapat digunakan untuk mendukung kegiatan belajar peserta didik dengan sistem pendidikan asrama (di lingkungan sekolah maupun lingkungan asrama).

e. Pengelolaan Pembiayaan

Dalam penyelenggaraan pendidikan berasrama, dana merupakan salah satu faktor penting untuk menyokong seluruh program maupun kegiatan yang ada. Oleh karena itu pengelolaan pembiayaan yang tepat guna dan tepat sasaran merupakan faktor pengelolaan yang perlu dikelola secara benar sehingga segala hal yang berhubungan dengan pencapaian visi misi dari pendidikan asrama dapat tercapai secara maksimal.

Salah satu lembaga pendidikan yang telah menerapkan sistem pendidikan asrama yaitu Sekolah Tinggi Theologi Sangkakala. Sekolah Tinggi Theologi Sangkakala (STT Sangkakala) telah menerapkan sistem pendidikan asrama sejak tahun 2002. Sistem pendidikan asrama ini diperuntukkan bagi seluruh mahasiswa yang berasal dari sabang sampai merauke Indonesia. STT Sangkakala merupakan salah satu sekolah tinggi yang menerapkan sistem pendidikan asrama untuk membentuk serta menghasilkan hamba Tuhan (pelayan Tuhan) yang berkualitas sesuai dengan program studi yang ditempuh oleh masing-masing mahasiswa. Adapun visi, misi, tujuan dan sasaran dari STT Sangkakala antara lain (Buku Profil STT Sangkakala):

Melalui penerapan sistem pendidikan asrama, STT Sangkakala meyakini bahwa visi, misi, tujuan dan sasaran yang dimiliki dapat dicapai secara maksimal. Namun pada kenyataannya di lapangan, sistem pendidikan berasrama yang diterapkan di STT Sangkakala masih mendapatkan beberapa kendala. Salah satu kendala utama yang sangat menonjol dalam pelaksanaannya yaitu belum adanya strategi dalam pengelolaan sekolah tinggi berasrama, dalam hal ini rencana strategi pengelolaan sekolah berasrama yang diterapkan di sekolah tinggi theologi Sangkakala belum ada. Sistem pendidikan 
berasrama yang telah berjalan selama ini, hanya dikelola melalui "buku aturan/pedoman" asrama yang dibuat oleh pihak Yayasan. Di dalam buku panduan terebut berisikan berbagai peraturan/rules dan prosedur yang harus dilakukan oleh penghuni asrama. Oleh karena belum adanya strategi pengelolaan asrama yang baik (paten), maka sistem pendidikan berasrama di sekolah STT Sangkakala masih belum dapat mencapai visi, misi, tujuan dan sasaran yang dimiliki secara efektif dan efisien.

Fakta mengenai belum adanya strategi pengelolaan asrama yang baik ini menimbulkan beberapa fenomena di lapangan dimana para dosen, orangtua asrama, serta mahasiswa (penghuni asrama) mengalami masalah dalam berbagai aspek terkait manajemen sekolah berasrama. Salah satu masalah yang terlihat jelas di lapangan yaitu seringkali terjadi misbehaviour para mahasiswa di lapangan. Beberapa contoh misbehaviour yang dimaksudkan seperti: keterlambatan dalam pengumpulan tugastugas kuliah, tidak menghargai dosen maupun pendamping asrama (adanya "pemberontakan" terhadap dosen maupun pendamping asrama), tidak mengikuti rules dan procedures yang ada di asrama (sumber: wawancara dengan kepala asrama dan dosen STTS - 21 September 2015).

Misbehaviour (sikap/tindakan menyimpang) yang terjadi dipengaruhi oleh beberapa faktor. Salah satu faktor yang sangat mempengaruhi adanya misbehaviour yaitu keberadaan pendamping asrama yang dipimpin oleh seorang pria (bapak) dengan tanggung jawab yang cukup berat yaitu harus menjadi pandamping bagi 90 mahasiswa penghuni asrama yang berasal dari berbagai suku dan budaya yang berbeda. Pendamping asrama tidak tinggal di dalam lingkungan asrama. Dengan kata lain, para penghuni asrama dituntut untuk mandiri dalam melaksanakan aktifitas kesehariannya di asrama. Pengawasan secara intensif terhadap keseharian mahasiswa di asrama cukup kurang.

Kurang efektifnya sistem pendampingan di asrama, berdampak pada pergumulan mahasiswa terkait pengerjaan tugas-tugas kuliah. Asrama STTS belum difasilitasi oleh layanan internet (akses wi-fi) dan perpustakaan kampus hanya dibuka hingga jam kerja selesai (antara jam 1 siang atau 3 sore). Adapun fasilitas internet disekitar kampus (24 jam), namun jarak antara asrama dan kampus cukup jauh jika harus berjalan malam hari. Mahasiswa benar-benar dituntut mandiri apabila memiliki kendala dalam pengerjaan tugas, mahasiswa harus bertanya langsung kepada dosen keesokan harinya. Mahasiswa tidak dapat memperkaya sumber informasi lain selain 
dosen oleh karena kendala yang telah dipaparkan. (sumber: wawancara dengan mahasiswa/mahasiswi STTS - 29 Oktober 2015).

Selanjutnya, mengingat bahwa penghuni asrama STT Sangkakala berasal dari berbagai suku di Indonesia, (Sabang sampai Merauke) yang secara otomatis memiliki latar belakang budaya yang berbeda pun menjadi salah satu penyebab pengelolaan asrama yang ada belum berjalan secara baik. Realita mengenai belum adanya strategi sekolah tinggi berasrama untuk STT Sangkakala dapat menghambat pencapaian visi, misi, tujuan, dan sasaran yang dimiliki dimana menghendaki lahirnya para pemimpin masa depan dalam hal ini para hamba Tuhan yang berintegritas tinggi dan berkompeten. Oleh karena itu, melalui penelitian ini diharapkan dapat menghasilkan strategi pengelolaan sekolah tinggi berasrama bagi STT Sangkakala sehingga visi, misi, tujuan, dan sasaran yang ada dapat tercapai secara efektif dan efisien.

Beberapa penelitian terdahulu yang relevan dengan penelitian ini antara lain penelitian berjudul "Keunggulan Pengelolaan Sekolah Berpola Asrama Seminari Menengah Petrus Van Diepen Sorong” yang dilakukan oleh Tan (2014). Penelitian ini membahas dan menganalisis keunggulan dalam pengelolaan sekolah berasrama di Seminari Menengah Petrus Van Diepen Sorong yaitu: (a) Sekolah khusus tapi terbuka untuk umum; (b) Pendidikan dan pembinaan manusia seutuhnya; (c) Prinsip 'non multa sed multum' (prinsip mementingkan mutu hidup seseorang daripada jumlah/kuantitas lulusan); (d) Keterarahan kepada anak-anak Papua; (e) Muatan lokal pengetahuan bahasa; (f) Manajemen pembinaan manusia utuh (pembinaan murid dan aturan disiplin).

Selanjutnya yaitu penelitian yang dilakukan oleh Papworth (2014) dengan judul “Attending Boarding School: A Longitudinal Study Of Its Role In Students' Academic And Non-Academic Outcomes”. Penelitian ini dilatarbelakangi oleh sistem sekolah berasrama yang ada di Australia dimana terdapat 170 sekolah berasrama. Adapun fokus dalam penelitian ini yaitu menganalisis permasalahan-permasalahan yang terjadi dalam sistem sekolah berasrama yang berpengaruh secara langsung terhadap pencapaian siswa baik secara akademik maupun non-akademik. Adapun permasalahan tersebut terkait manajemen pengelolaan sekolah berasrama yang dipengaruhi oleh berbagai faktor.

Penelitian oleh Curto \& Fryer (2012) berjudul "The Potential of Urban Boarding Schools for the Poor: Evidence from SEED”. Dalam penelitian ini dijabarkan mengenai strategi pengelolaan sekolah berasrama yang dilakukan di Amerika Serikat di sekolah SEED dengan memaksimalkan berbagai program untuk siswa berasrama. 
Melalui penelitian tersebut peneliti menelaah mengenai berbagai masalah yang dihadapi oleh sekolah berasrama secara khusus sekolah berasrama yang dikhususkan bagi siswa yang kurang mampu secara ekonomi (miskin). Adapun beberapa hal yang ditelaah yaitu terkait pengelolaan sekolah berasrama, pengelolaan biaya, pengelolaan SDM sekolah berasrama (kepala sekolah dan kepala asrama). Selanjutnya dalam penelitian ini, peneliti pun menyatakan bahwa sekolah dengan pola asrama seharusnya dapat memberikan kontribusi yang lebih baik dalam pembentukan karakter serta sikap peserta didik dibandingkan ketika mereka berada di lingkungan rumah. Hal sebaliknya dapat terjadi yaitu sistem pola asrama tidak mampu membentuk karakter serta sikap siswa menjadi lebih baik ketika tidak adanya pengaturan (manajemen) yang baik dalam pengelolaannya.

Penelitian oleh Schaverien (2004) yang berjudul "Boarding School : the trauma of the 'privileged' child". Penelitian ini dilatarbelakangi oleh keadaan psikologis peserta didik saat berada di tengah-tengah lingkungan rumah (masyarakat) yang cukup rentan dengan berbagai hal negatif seperti pergaulan bebas, tindakan tidak menghargai sesama, dll. Oleh karena itu, melalui penelitian ini peneliti memaparkan dan menelaah mengenai kondisi psikologis siswa yang tinggal di sekolah berasrama. Melalui sistem sekolah berasrama diyakini bahwa siswa dapat memiliki kehidupan yang jauh lebih baik dibandingkan di lingkungan rumahnya jika sekolah asrama memiliki pengelolaan yang baik. Jika pengelolaan sekolah berasrama tidak tepat/baik dalam pelaksanaannya maka pencapaian siswa untuk menjadi siswa yang sukses secara holistik pun tidak dapat tercapai. Trauma-trauma yang buruk dapat terjadi ketika pengelolaan sekolah berasrama tidak diatur dengan baik, seperti: siswa akan bertumbuh dan melakukan halhal yang buruk (memberontak terhadap aturan/sistem sekolah asrama yang ada).

Penelitian oleh Iswanti (2010) yang berjudul "Pembentukan Sikap dan Kepribadian Guru Melalui Model Pendidikan Berasrama”. Penelitian ini bertujuan untuk menganalisis mengenai pengaruh model pendidikan berasrama bagi para calon guru yang menjadi penghuni asrama di FIP UNY, Yogyakarta. Berdasarkan hasil penelitian, peneliti memberikan rekomendasi terkait strategi dalam pengelolaan asrama yaitu pembentukan sikap dan kepribadian mahasiswa calon guru sekolah dasar (PGSD) yang tinggal di asrama lebih efektif menggunakan pendekatan bimbingan individual yaitu melalui konseling daripada bimbingan secara kelompok atau klasikal. Melalui pendekatan secara individual, maka akan terjadi hubungan yang lebih intensif antara kepala asrama dengan mahasiswa penghuni asrama. Melalui sistem seperti ini maka 
visi dan misi dari pelaksanaan model asrama dapat tercapai melalui pembentukan sikap dan kepribadian calon guru yang dilakukan secara personal (pendekatan individual).

Sejalan dengan latarbelakang permasalahan di atas, maka rumusan masalah dalam penelitian ini adalah: 1) Strategi apa yang telah digunakan dalam pengelolaan sekolah tinggi berasrama di STT Sangkakala?; 2) Apa saja yang menjadi akar permasalahan dalam pengelolaan sekolah tinggi berasrama di STT Sangkakala?; 3) Strategi apa yang dapat digunakan oleh STT Sangkakala dalam mengelola sekolah tinggi berasrama berdasarkan hasil analisis fishbone?. Berdasarkan rumusan masalah yang telah dipaparkan maka penelitian ini bertujuan untuk: 1) Mengetahui dan menganalisis strategi pengelolaan berasrama yang telah digunakan oleh STT Sangkakala; 2) Menganalisis akar permasalahan dalam pengelolaan sekolah tinggi berasrama di STT Sangkakala; dan 3) Merancang dan menghasilkan strategi yang dapat diterapkan oleh STT Sangkakala dalam pengelolaan sekolah tinggi berasrama.

Selanjutnya teoritis dari penelitian ini yaitu memberikan kontribusi akademis dalam bidang manajemen pendidikan berupa kajian tentang strategi untuk mengelola sekolah berasrama. Sedangkan manfaat praktis dari penelitian ini adalah: 1) Memberikan informasi kepada pihak sekolah terkait akar permasalahan mengenai pengelolaan sekolah berasrama di STT Sangkakala yang belum berjalan secara baik; 2) Memberikan masukan kepada pihak sekolah berupa strategi untuk mengatasi permasalahan mengelola sekolah berasrama yang didokumentasikan dalam bentuk produk (rencana strategis/renstra) pengelolaan sekolah tinggi theologi berasrama Sangkakala.

\section{METODE PENELITIAN}

Penelitian ini merupakan penelitian pengembangan. Van Den Akker (1999) menyatakan bahwa penelitian pengembangan merupakan jenis penelitian yang bertujuan untuk menghasilkan produk tertentu dan menguji keefektivitasan produk tersebut. Namun, dalam penelitian ini akan dibatasi hanya pada penghasilan suatu produk yaitu merancang strategi pengelolaan sekolah berasrama di sekolah tinggi theologi Sangkakala. Penelitian ini akan dilakukan di sekolah tinggi theologi Sangkakala yang berlokasi di di kampung Kenteng Jl. Raya Kopeng KM 7, Salatiga. Rencana pengumpulan data akan dilakukan pada bulan Oktober 2015. Alasan pemilihan sekolah tinggi theologi Sangkakala karena sekolah tinggi theologi ini telah menerapkan sistem sekolah berasrama sejak tahun 2002 namun hingga saat ini masih 
belum mempunyai strategi pengelolaan sekolah berasrama. Subjek penelitian dalam penelitian ini adalah puket 3 (pembantu rektor 3 - bagian kemahasiswaan yang bertanggung jawab langsung terkait pengelolaan asrama), dosen, mahasiswa, orangtua asrama, dan komite sekolah tinggi (pihak lain di luar kampus/STT). Pengumpulan data akan dilakukan melalui observasi, wawancara, Focus Group Discussion (FGD), dan studi dokumentasi.

Observasi dilakukan oleh peneliti di dua asrama yang ada di STT Sangkakala (asrama putri dan asrama putra) untuk mengidentifikasi akar permasalahan yang terjadi. Selain itu, observasi dilakukan di kampus (proses perkuliahan berlangsung) untuk mengidentifikasi interaksi antara dosen pengajar dan mahasiswa STT Sangkakala. Wawancara dilakukan untuk menggali informasi terkait akar permasalahan pengelolaan asrama STT Sangkakala. Wawancara dilakukan bersama puket 3 (pembantu rektor 3) yang bertanggung jawab atas pengelolaan asrama, puket 2 (pembantu rektor 2) yang bertanggung jawab langsung terhadap penananganan kurikulum (prestasi mahasiswa), kepala asrama (pendamping asrama), bendahara, mahasiswa (penghuni asrama), dosen, komite sekolah. Di samping sebagai teknik menggali informasi, wawancara dilakukan sebagai teknik trianggulasi sumber. FGD dilakukan dengan melibatkan puket 3 (pembantu rektor 3), puket 1 (pembantu rektor 1) yang bertanggung jawab terakait kurikulum (prestasi mahasiswa), kepala asrama, dosen, mahasiswa, bendahara, komite sekolah. Dalam FGD tersebut, terjadi proses brainstorming untuk menentukan akar permasalahan pengelolaan asrama STT Sangkakala. Studi dokumentasi dilakukan bertujuan untuk mencari informasi tertulis berkaitan dengan faktor permasalahan pengelolaan asrama berupa profil sekolah, rencana strategi sekolah, pedoman asrama, serta prestasi akademik maupun non akademik mahasiswa.

Teknik analisis data yang digunakan adalah teknik analisis fishbone (Ishikawa, 1989). Langkah pertama yaitu potensi masalah serta langkah keduanya yaitu pengumpulan data dilakukan untuk mencari faktor penyebab pengelolaan asrama STT Sangkakala yang belum berjalan secara baik. Selanjutnya, faktor penyebab permasalahan tersebut dipetakan dalam diagram tulang ikan (fishbone). Faktor-faktor yang diidentifikasi dibatasi pada faktor-faktor penting berdasarkan kajian teori oleh Tan (2014) dalam pengelolaan sekolah berasrama yaitu pengelolaan kurikulum, peserta didik, tenaga pendidik dan kependidikan, sarana dan prasarana, dan pembiayaan. Namun berdasarkan hasil penelitian, data di lapangan menunjukkan bahwa terdapat empat faktor yang mempengaruhi pengelolaan asrama STT Sangkakala yaitu 
pengelolaan kurikulum dan pembinaan, pengelolaan peserta didik, pengelolaan tenaga pendidik dan kependidikan, serta kebijakan pemimpin (ketua Yayasan).

\section{HASIL PENELITIAN}

Berdasarkan data penelitian di lapangan melalui observasi, wawancara, dan FGD, telah diperoleh hasil penelitian terkait akar permasalahan pengelolaan asrama STT Sangkakala yang dipengaruhi oleh empat faktor yaitu pengelolaan kurikulum dan pembinaan, pengelolaan peserta didik, pengelolaan tenaga pendidik dan kependidikan, serta kebijakan pemimpin (ketua). Akar permasalahan dalam pengelolaan kurikulum disebabkan oleh belum dimodifikasinya kurikulum baru oleh staff (Puket 1 bersama staff administrator lainnya). Modifikasi kurikulum yang dimaksudkan yaitu perpaduan antara kurikulum dari pemerintah pusat dan ketetapan dari BAN (Badan Akreditasi Nasional). Akar permasalahan yang telah diidentifikasi tersebut dapat dilihat melalui Gambar 1 Diagram Fishbone Pengelolaan Asrama STT Sangkakala. 
Gambar 1

Diagram Fishbone

Pengelolaan Asrama STT Sangkakala

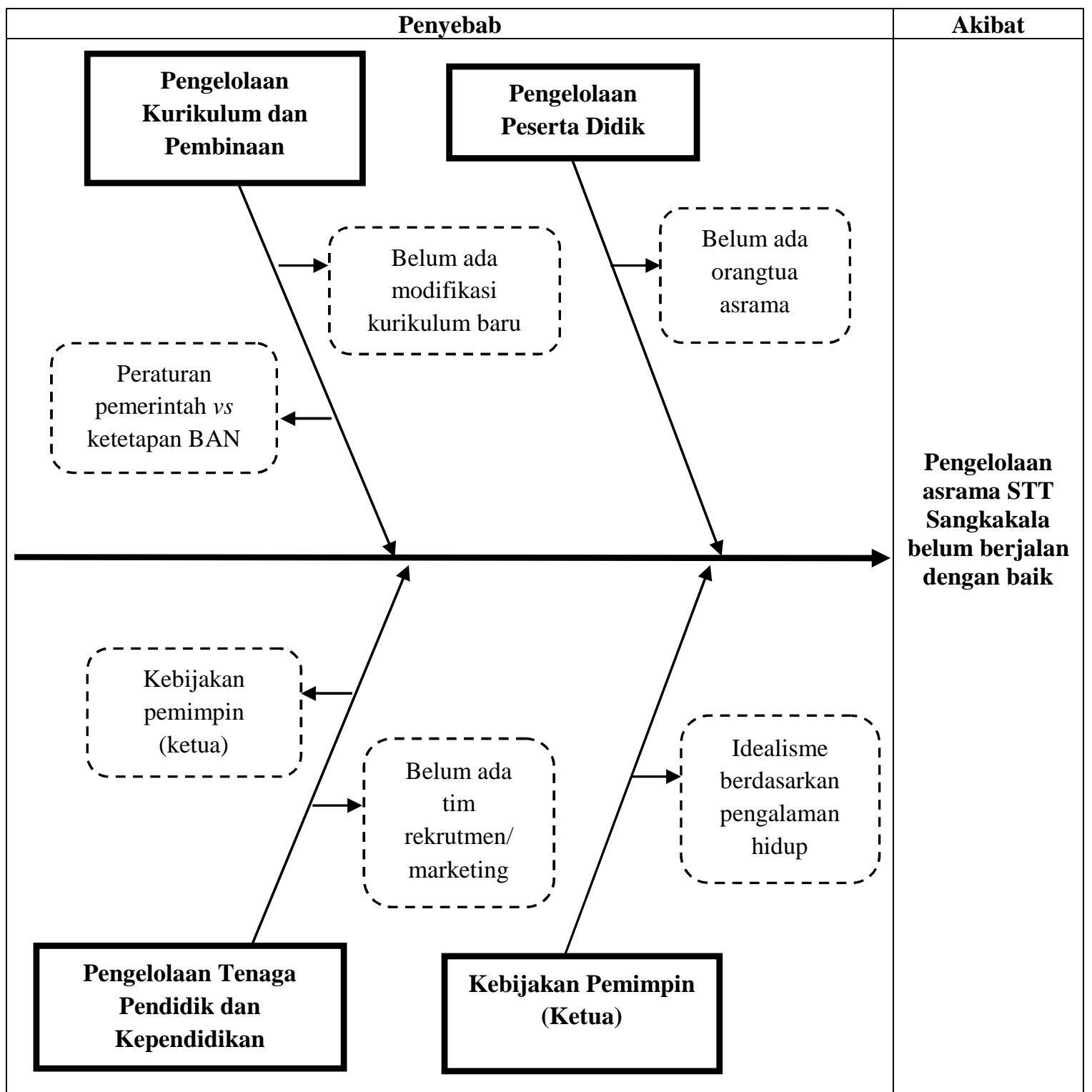

Selanjutnya akar permasalahan dalam pengelolaan peserta didik yaitu tidak ada orangtua asrama yang tinggal bersama dengan mahasiswa. Akar permasalahan selanjutnya yaitu dalam pengelolaan tenaga pendidik dan kependidikan disebabkan oleh belum adanya tim rekrutmen dan kebijakan pimpinan (ketua). Faktor terakhir yang begitu kuat pengaruhnya terhadap pengelolaan asrama STT Sangkakala yaitu kebijakan pemimpin (ketua) yang disebabkan oleh pengalaman-pengalam beliau di masa lalu (idealisme berdasarkan pengalaman hidup). Setelah mengidentifikasi akar permasalahan yang dilakukan melalui teknik analisis fishbone, maka tahapan selanjutnya adalah menyusun desain produk berupa strategi pengelolaan asrama STT 
Sangkakala. Strategi disusun berdasarkan analisis fishbone dan analisis kebutuhan yang didapat melalui FGD, wawancara, dan observasi. Strategi yang disusun dapat dilihat dalam Tabel 1 Strategi Pengelolaan Asrama STT Sangkakala.

Tabel 1 Strategi Pengelolaan Asrama STT Sangkakala

\begin{tabular}{|c|c|c|}
\hline No & Faktor & Strategi \\
\hline 1 & $\begin{array}{l}\text { Pengelolaan Kurikulum dan } \\
\text { Pembinaan }\end{array}$ & $\begin{array}{l}\text { - Pembentukan tim penyusun kurikulum yang berkualitas } \\
\text { - Mengembangkan kurikulum yang inovatif berbasis } \\
\text { pengalaman dunia luar dan kebutuhan mahasiswa } \\
\text { - Mengembangkan kualitas pengajar/dosen secara berkala } \\
\text { dan terencana berbasis pada kebutuhan mahasiswa }\end{array}$ \\
\hline 2 & Pengelolaan Peserta Didik & $\begin{array}{l}\text { - Merekrut orangtua asrama dan staff lainnya yang } \\
\text { dibutuhkan untuk ditempatkan di asrama } \\
\text { - Menerapkan sistem parenting dormitory berikut ini: Dorm } \\
\text { Parents, Residence Assistant, dan Supervisor } \\
\text { - Menyusun program-program yang inovatif bagi } \\
\text { mahasiswa yang tepat sasaran untuk membentuk CASH } \\
\text { (Character, Skill, Attitude, dan Habit) mahasiswa yang } \\
\text { berkualitas secara holistik }\end{array}$ \\
\hline 3 & $\begin{array}{c}\text { Pengelolaan Tenaga Pendidik } \\
\text { dan Kependidikan }\end{array}$ & $\begin{array}{l}\text { - Membentuk tim rekrutmen/marketing untuk } \\
\text { mempromosikan STT Sangkakala secara berkala } \\
\text { disesuaikan dengan kebutuhan di lapangan } \\
\text { - Mengembangkan kualitas tenaga pendidik dan } \\
\text { kependidikan secara berkala sesuai evaluasi di lapangan } \\
\text { dan berbasis pada kebutuhan siswa (terencana dan tepat } \\
\text { sasaran) } \\
\text { - Menyusun hasil evaluasi secara berkala dari masing- } \\
\text { masing Puket (pembantu ketua/wakil ketua) berdasarkan } \\
\text { realita di lapangan secara sistematis dan ter-update kepada } \\
\text { pemimpin }\end{array}$ \\
\hline 4 & Kebijakan Pemimpin (Ketua) & $\begin{array}{l}\text { - Memaksimalkan peran setiap Puket yang ada (Puket } 1 \text { dan } \\
\text { Puket 3) melalui diskusi (evaluasi dan monitoring) yang } \\
\text { aktif dari kedua pihak } \\
\text { - Meningkatkan kepekaan dan ketangkasan dalam } \\
\text { menanggapi hal-hal urgensi di lapangan melalui analisis } \\
\text { hasil evaluasi ter-update terkait pengelolaan asrama STT } \\
\text { Sangkakala } \\
\text { - Mengadakan studi banding secara berkala bersama } \\
\text { leadership team ke lembaga-lembaga sekolah tinggi } \\
\text { lainnya yang telah terbukti keunggulannya dalam } \\
\text { pengelolaan sekolah berasrama }\end{array}$ \\
\hline
\end{tabular}

\section{PEMBAHASAN}

\section{a. Pengelolaan kurikulum dan pembinaan}

Akar permasalahan yang diidentifikasi dalam faktor pengelolaan kurikulum dan pembinaan yaitu belum ada modifikasi kurikulum baru oleh Puket 1 beserta staff lainnya yang bertanggung jawab dalam bagian pengelolaan kurikulum STT 
Sangkakala. Belum adanya modifikasi kurikulum baru disebabkan oleh peraturan kurikulum pemerintah yang harus disesuaikan dengan ketetapan BAN sehingga dalam implementasi kurikulum di lapangan tidak terdapat masalah.

Faktor pengelolaan kurikulum dan pembinaan merupakan salah satu faktor penentu dalam pengelolaan sekolah berasrama. Tan (2014) menyatakan bahwa pengelolaan kurikulum dan pembinaan merupakan faktor pengelolaan sekolah berasrama yang menjadi salah satu penentu keberhasilan tercapainya visi dan misi sekolah. Melalui pengelolaan kurikulum dan pembinaan yang tepat sasaran terhadap peserta didik maka visi dan misi sekolah dapat tercapai secara efektif dan efisien.

Senada dengan hal tersebut, Papworth (2014) mengungkapkan bahwa melalui pengelolaan kurikulum yang benar maka tujuan yang dimiliki oleh sekolah terhadap peserta didik yang tinggal di asrama dapat tercapai secara maksimal. Oleh karena itu, pengelolaan kurikulum dan pembinaan yang benar serta tepat sasaran sangat dibutuhkan dalam pengelolaan sekolah tinggi berasrama STT Sangkakala.

\section{b. Pengelolaan peserta didik}

Pengelolaan peserta didik ini terkait mengenai proses pembentukan karakter serta kesuksesan secara holistik yang seharusnya dicapai oleh setiap peserta didik yang menempuh pendidikan berasrama. Schaverien (2004) mengungkapkan bahwa melalui sistem sekolah berasrama diyakini bahwa siswa dapat memiliki kehidupan yang jauh lebih baik dibandingkan di lingkungan rumahnya jika sekolah asrama memiliki pengelolaan yang baik. Jika pengelolaan sekolah berasrama tidak tepat dalam pelaksanaannya maka pencapaian siswa untuk menjadi siswa yang sukses secara holistik pun tidak dapat tercapai. Trauma-trauma yang buruk dapat terjadi ketika pengelolaan sekolah berasrama tidak diatur dengan baik, seperti: siswa akan bertumbuh dan melakukan hal-hal yang buruk (memberontak terhadap aturan ataupun sistem sekolah asrama yang ada).

Akar permasalahan yang diidentifikasi pada faktor pengelolaan peserta didik, yaitu belum adanya orangtua asrama sehingga tidak ada role model bagi setiap penghuni asrama. Fakta mengenai belum adanya orangtua asrama yang menjadi role model bagi mahasiswa penghuni asrama mengakibatkan masalah bermunculan ditengah-tengah mahasiswa. Mahasiswa yang berasal dari berbagai daerah dengan latar belakang budaya serta keluarga yang berbeda-beda, membutuhkan figur orangtua yang mampu membimbing, mengayomi, memberikan teladan hidup bagi mereka. 
Berdasarkan hasil wawancara dan FGD, keterdesakan adanya orangtua asrama yaitu agar mahasiswa mendapatkan figur orangtua yang benar (tidak hanya sekedar bekerja sebagai staff asrama). Hal tersebut mengingat bahwa ada mahasiswa yang tidak memiliki gambaran mengenai keluarga yang utuh (orangtua yang meninggal ataupun berpisah). Akar permasalahan lainnya terkait pengelolaan peserta didik yaitu kebijakan pemimpin yang menghendaki agar setiap mahasiswa mampu hidup mandiri di asrama.

\section{c. Pengelolaan tenaga pendidik dan kependidikan}

Pengelolaan tenaga pendidik dan kependidikan merupakan faktor pengelolaan terkait kualifikasi tenaga pengajar dan pembina asrama (orangtua asrama atau kepala asrama). Kualifikasi tenaga pengajar dan pembina asrama merupakan salah satu faktor yang penting peranannya dalam menjalankan pendidikan berasrama oleh karena pihakpihak tersebut berperan secara langsung di lapangan dalam pembentukan kesuksesan peserta didik secara holistik.

Hal senada diungkapkan oleh Curto \& Fryer (2012), adapun beberapa hal yang ditelaah yaitu terkait pengelolaan sekolah berasrama, pengelolaan biaya, pengelolaan SDM sekolah berasrama (kepala sekolah dan kepala asrama). Sekolah berasrama dengan pengelolaan SDM yang baik dapat menghasilkan peserta didik yang berhasil dan sukses baik secara akademik maupun non akademik. Sekolah dengan pola asrama seharusnya dapat memberikan kontribusi yang lebih baik dalam pembentukan karakter serta sikap peserta didik dibandingkan ketika mereka berada di lingkungan rumah. Hal sebaliknya dapat terjadi yaitu sistem pola asrama tidak mampu membentuk karakter serta sikap siswa menjadi lebih baik ketika tidak adanya pengaturan (manajemen) yang baik dalam pengelolaannya.

Pada faktor pengelolaan tenaga pendidik dan kependidikan akar permasalahan yang diidentifikasi pada faktor pengelolaan tenaga pendidik dan kependidikan yaitu belum ada tim rekrutmen atau marketing dan kebijakan pemimpin (ketua). Pengelolaan tenaga pendidik dan kependidikan yang dimaksudkan yaitu terkait bagaimana mengelola setiap staff yang ada termasuk dalam hal cukupnya jumlah staff dalam memenuhi kebutuhan mahasiswa. Istilah cukupnya staff yang dimaksudkan bukan hanya cukup secara kuantitas namun juga dalam kualitasnya. Kualitas yang sesuai untuk memenuhi kebutuhan mahasiswa sebagai peserta didik sehingga visi, misi, dan tujuan STT Sangkakala dapat tercapai dengan maksimal.

Berdasarkan hasil wawancara dan FGD, akar permasalahan pada pengelolaan tenaga pendidik dan kependidikan yaitu STT Sangkakala belum memiliki strategi 
dalam perekrutan orangtua asrama/staff yang dapat menangani asrama secara intensif. Fakta lainnya yaitu belum adanya tim rekrutmen dan juga pemimpin (ketua) yang belum menanggapi permasalahan pengelolaan asrama sebagai hal urgensi yang perlu ditangani dengan segera menjadi akar permasalahan dalam pengelolaan tenaga pendidik dan kependidikan. Selain itu, tenaga staff yang ada pun dalam hal ini kepala asrama tidak dibekali dengan pelatihan-pelatihan atau monitoring secara berkesinambungan dari pihak pemimpin yang ada.

\section{d. Kebijakan pemimpin}

Pada faktor kebijakan pemimpin dimana akar permasalahan yang diidentifikasi adalah idealisme berdasarkan pengalaman hidup. Kebijakan pemimpin (ketua) sangat mempengaruhi pengelolaan asrama STT Sangkakala. Hal ini diungkapkan oleh Curto \& Fryer (2012) bahwa pengelolaan SDM, termasuk di dalamnya yaitu pemimpin memiliki peranan penting dalam pengelolaan sekolah berasrama. Keputusan-keputusan yang dibuat oleh pemimpin seharusnya dapat memberikan hasil yang baik untuk ketercapaian visi dan misi dari sekolah asrama. Ketika pemimpin tidak menghasilkan keputusan-keputusan yang tepat (kontra-produktif) maka ketercapaian visi dan misi yang melibatkan berbagai faktor pengelolaan sekolah berasrama dapat terhambat.

Pemimpin (ketua) STT Sangkakala memiliki pandangan bahwa setiap mahasiswa perlu di didik secara mandiri (tidak manja) sesuai dengan pengalaman beliau di masa lalu. Menurut pemimpin, kemandirian yang tinggi akan membentuk pribadi generasi muda yang menghargai dan menikmati setiap proses menuju pendewasaan holistik. Oleh karena itu, selama ini masalah-masalah dalam pengelolaan asrama dianggap telah ditangani dengan cukup maksimal dilakukan berdasarkan idealisme yang dimiliki oleh pemimpin.

Kebijakan pemimpin yang akan menghasilkan keputusan-keputusan terkait pengelolaan asrama sangat mempengaruhi dalam pengelolaan asrama STT Sangkakala. Isu permasalahan pengelolaan asrama yang sebenarnya telah menjadi masalah klasik tersebut, belum juga mendapatkan respon yang signifikan dari pemimpin. Oleh karena itu, perubahan paradigma serta strategi pemimpin dalam pengelolaan asrama sangatlah diperlukan sehingga visi, misi, tujuan dan sasaran berdirinya STT Sangkakala dapat tercapai secara maksimal.

\section{SIMPULAN DAN SARAN}


Hasil analisis akar permasalahan ditinjau dari faktor pengelolaan kurikulum dan pembinaan adalah belum ada modifikasi kurikulum baru disebabkan oleh peraturan kurikulum pemerintah yang harus disesuaikan dengan ketetapan BAN. Pada faktor pengelolaan peserta didik, akar permasalahan yang diidentifikasi yaitu belum adanya orangtua asrama. Selanjutnya, pada faktor pengelolaan tenaga pendidik dan kependidikan, akar permasalahannya adalah belum ada tim rekrutmen atau marketing dan kebijakan pemimpin (ketua). Pada faktor kebijakan pemimpin, akar permalasahan yang diidentifikasi adalah idealisme pemimpin yang didasarkan pada pengalaman hidup.

Berdasarkan hasil analisis masalah dan kebutuhan, maka strategi yang dirumuskan dikelompokkan menjadi empat faktor pengelolaan asrama yaitu faktor pengelolaan kurikulum dan pembinaan, pengelolaan peserta didik, pengelolaan tenaga pendidik dan kependidikan, serta kebijakan pemimpin (ketua). Strategi yang dirumuskan untuk faktor pengelolaan kurikulum dan pembinaan meliputi: 1) Pembentukan tim penyusun kurikulum yang berkualitas, 2) Mengembangkan kurikulum yang inovatif berbasis pengalaman dunia luar dan kebutuhan mahasiswa, 3) Mengembangkan kualitas pengajar/dosen secara berkala dan terencana berbasis pada kebutuhan mahasiswa. Strategi yang disarankan pada faktor pengelolaan peserta didik yaitu: 1) Merekrut orangtua asrama dan staff lainnya yang dibutuhkan untuk ditempatkan di asrama, 2) Menerapkan sistem parenting dormitory berikut ini: Dorm Parents, Residence Assistant, dan Supervisor, 3) Menyusun program-program yang inovatif bagi mahasiswa yang tepat sasaran untuk membentuk CASH (Character, Skill, Attitude, dan Habit) mahasiswa yang berkualitas secara holistik.

Selanjutnya strategi pada faktor pengelolaan tenaga pendidik dan kependidikan yaitu: 1) Membentuk tim rekrutmen atau marketing untuk mempromosikan STT Sangkakala secara berkala disesuaikan dengan kebutuhan di lapangan, 2) Mengembangkan kualitas tenaga pendidik dan kependidikan secara berkala sesuai evaluasi di lapangan dan berbasis pada kebutuhan siswa (terencana dan tepat sasaran), 3) Menyusun hasil evaluasi secara berkala dari masing-masing Puket (pembantu ketua/wakil ketua) berdasarkan realita di lapangan secara sistematis dan ter-update kepada pemimpin. Strategi pada faktor kebijakan pemimpin adalah 1) Memaksimalkan peran setiap Puket yang ada (Puket 1 dan Puket 3) melalui diskusi (evaluasi dan monitoring) yang aktif dari kedua pihak, 2) Meningkatkan kepekaan dan ketangkasan 
dalam menanggapi hal-hal urgensi di lapangan melalui analisis hasil evaluasi ter-update terkait pengelolaan asrama STT Sangkakala, 3) Mengadakan studi banding secara berkala bersama leadership team ke lembaga-lembaga sekolah tinggi lainnya yang telah terbukti keunggulannya dalam pengelolaan sekolah berasrama.

Berdasarkan hasil penelitian, saran yang dihasilkan adalah sebagai berikut:

1. Yayasan sebagai pihak utama yang menaungi STT Sangkakala diharapkan selalu berperan aktif dalam implementasi rencana strategis pengelolaan asrama. Disamping hal tersebut, pihak yayasan diharapkan untuk bisa dengan cepat dan berani untuk mengambil keputusan untuk mengatasi permasalahan yang dihadapi oleh STT Sangkakala.

2. Kepemimpinan ketua (rektor) sangat berperan penting dalam menjalankan rencana strategis pengelolaan asrama STT Sangkakala Kopeng. Ketua, dalam hal ini rektor dapat mempertimbangkan untuk mengimplementasikan rencana strategis dan program-program yang diusulkan demi mencapai visi, misi, tujuan, serta sasaran dari STT Sangkakala. Disamping hal tersebut, komunikasi aktif dengan para staff lainnya terutama Puket 3 dan kepala asrama sangatlah diperlukan untuk memantau serta memastikan pengelolaan asrama STT Sangkakala telah berjalan dengan baik.

3. Dosen sebagai ujung tombak pelaksanaan proses belajar mengajar perlu berkomitmen dan konsisten dalam melaksanakan rencana strategis, terutama dalam upaya peningkatan pengelolaan kurikulum dan pembinaan serta pengelolaan peserta didik. Dosen dan staff diharapkan senantiasa meningkatkan profesionalitas, kemampuan dan keahlian sesuai perkembangan teknologi dan informasi.

\section{Daftar Pustaka}

Curto \& Fryer. (2012). The Potential Of Urban Boarding Schools for the Poor: Evidence from SEED. Journal of Education, 23 (2)

Ishikawa, K. (1989). Teknik Penuntun Pengendalian Mutu. Jakarta: PT Mediyatama Sarana Perkasa.

Iswanti. (2010). Pembentukan Sikap dan Kepribadian Guru Melalui Model Pendidikan Berasrama. Diakses pada 20 Juni 2015 dari http://staff.uny.ac.id/sites/default/files/Artikel\%20penelitian\%20asrama.pdf

Papworth, B. (2014). Attending Boarding School: A Longitudinal Study Of Its Role In Students' Academic And Non-Academic Outcomes. Diakses pada 28 Juli 2015 dari http://www.sydney.edu.au/copyright 
Strategi Pengelolaan Sekolah Tinggi Berasrama di Kabupaten Semarang | Noveliza R.T. Tepy

Schaverien. (2004). Boarding School : the trauma of the 'privileged' child". Journal of Analytical Psychology, 2004, 49, 683-705.

Tan, I. (2014). Keunggulan Pengelolaan Sekolah Berpola Asrama Seminari Menengah Petrus Van Diepen Sorong. Universitas Kristen Satya Wacana.

Van Den Akker. (1999). Principles and Methods of Development Research. Dortrech: Kluwer Academic Publishers. 